\title{
Evaluation of Blood Lead Levels (Bll) of Albino Rat Offspring (Weanlings) Prenatally Exposed to Lead and Moringa Oleifera
}

\author{
Jackson I Osuh $^{1^{*}} \mid$ Adegbenga M Sunmola $^{2} \mid$ Shyngle K Balogun $^{2} \mid$ Ajibola A Ishola $^{2}$
}

${ }^{1}$ Department of Psychology,
Faculty of Social Science, Federal
University, OyeEkiti, Nigeria
${ }^{2}$ Department of Psychology,
Faculty of the Social Sciences,
University of Ibadan, Ibadan,
Nigeria

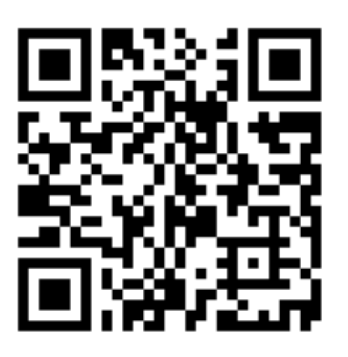

\begin{abstract}
This study evaluated the presence of lead in the offspring (weanlings) of prenatally exposed rats and the ameliorative effect of Moringa oleifera (MO). Independent group randomized design in a $3 \times 4$ factorial matrix was adopted. A total of 120 Wister Albino rat weanlings randomly selected from 490 offspring prenatally exposed to lead and MO and assigned into 12 treatment groups of 10 rats each were used. Multivariate Analysis variance at 0.05 level of significance was adopted. Rat weanlings prenatally exposed to higher lead doses had more lead in their blood compared to rat weanlings exposed to MO combined with lead, rat weanlings exposed to lead only and rat weanlings exposed to MO only. Lead was present in the blood of rat weanlings prenatally exposed to lead while non was recorded in blood of rat weanlings exposed to MO and the controls. Control of environmental lead is therefore imperative.

Keywords: Lead, Moringa oleifera, Blood Lead Level (BLL), Albino Rats, Offspring

Copyright : (C) 2021 The Authors. Published by Medical Editor and Educational Research Publishers Ltd. This is an open access article under the CC BY-NC-ND license

(https://creativecommons.org/licenses/by-nc-nd/4.0/).
\end{abstract}

\section{1 | INTRODUCTION}

$\mathrm{M}$ easurement of Blood Lead Level (BLL) is very critical in understanding the major health hazards associated with exposure to lead, Particularly in children; this need regular monitoring in order to avoid lead exposure as much as possible (H. Needleman, 2009). There are several research evidence showing behavioral deficits associated with high BLL mostly in children (Liu et al., 2011 Tatsuta et al., 2020; Abushady et al., 2017).

Lead is a hazardous chemical which occurs naturally and categorized as a heavy metal and also nonbiodegradable. Lead is used extensively in production and recycling of batteries, paints, lead containing gasoline, and for several other purposes resulting 


\section{MEERP LTD}

into extensive contamination of the environment and exposure to humans and animals, causing significant community health problems in various parts of the world (Al-Megrin et al., 2020). World Health Organization (WHO) report of 2016 indicate that exposure to lead through human activities accounted for an estimated death of 143,000 people who die every year, accounting for $0.6 \%$ of the worldwide disease burden. (WHO, 2016).

Lead is a toxin that accumulates in the body and damages many physiological systems (WHO, 2020). It has substantial consequences for the central nervous system, hematologic, reproductive, hepatic, and excretory systems (Obeng-Gyasi et al., 2018 Qi et al., 2019). The amount of lead collected in the body is accounted for by blood lead levels, although nothing is known about the safe blood lead level. However, other studies have found that a low lead level of 5 $\mathrm{g} / \mathrm{dL}$ can contribute to decreased intellect in children, learning impairments, and behavioral issues (Mason et al., 2014). The impacts of lead toxicity are more severe in developing countries because they are predominantly at high risk of lead toxicity, and they bear the highest burden of this hazard, according to a WHO report ((WHO, 2020).

According to Yousef et al.,(2019), Lead can enter the body through a variety of methods, including inhalation, skin absorption, and ingestion of contaminated food or water. Several researches indicate that after absorption, lead is transported from the bloodstream and deposited in the soft tissues of living organisms (Al-Quraishy et al., 2016 Aladaileh et al., 2020). Lead is recognized to be hazardous, especially to developing neural systems. Lead can pass from a pregnant woman's placenta to the fetus or from breast milk to a baby, indicating that safeguarding infants from lead exposure is critical for lifetime

Supplementary information The online version of this article (https://doi.org/10.52845/JMRHS/20214-12-3) contains supplementary material, which is available to authorized users.

Corresponding Author: Jackson I Osuh

Department of Psychology, Federal University OyeEkiti, Nigeria health. There is evidence that even at low levels of lead in the blood, lead can impact IQ, attention span, and academic accomplishment (Aladaileh et al., 2020).

Because children are exposed to lead throughout their lives, they are more vulnerable to lead poisoning than adults. If their mothers have lead in their bodies, they might well be exposed to lead in the womb. Babies can consume lead when they breastfeed, eat other meals, or drink lead-contaminated water (Aziz et al., 2012 ATSDR, 2020). While playing on the floor or the ground, babies and children might swallow and breathe lead from dirt, dust, or sand. Children are more likely than adults to be exposed to lead as a result of these activities. Lead particles may be present in the soil or dust on the children's hands, toys, and other items. In other situations, children ingest nonfood substances like paint chips, which can contain extremely high levels of lead, especially in and around older buildings painted with lead-based paint. The paint on these structures frequently peels and combines with dust and filth. Children are more vulnerable to the health impacts of lead than adults, and there is no acceptable blood lead level in children (CDC, 2012 Mazumdar et al., 2011).

Lead affects children differently depending on how much lead they consume. A child that consumes excessive levels of lead may suffer anemia, renal damage, colic (severe "gut ache"), muscle weakness, and brain damage, all of which can be fatal (CDC, 2012). In rare situations, the amount of lead in a child's body can be reduced by administering particular medications that aid in the elimination of lead from the body. Smaller amounts of lead, such as dust containing lead from paint, may be swallowed by a kid, causing far less severe but nonetheless significant effects on blood, development, and behavior. Recovery is expected in this situation after the child is removed from the source of lead exposure, but there is no guarantee that the newborn will totally avoid the long-term repercussions of lead poisoning. Lead can harm a child's mental and physical development even at low levels of exposure. Fetuses exposed to lead in the womb as a result of their mothers' high lead levels may be born prematurely and with lower birth weights (ATSDR, 2020). Exposure during pregnancy, infancy, or early childhood may also 


\section{EVALUATION OF BLOOD LEAD LEVELS (BLL) OF ALBINO RAT OFFSPRING (WEANLINGS) PRENATALLY EXPOSED TO LEAD AND MORINGA OLEIFERA}

impede mental development and result in poorer IQ later in life. Lead is highly hazardous to the nervous system, especially throughout the developing stages of life (Baranowska-Bosiacka et al., 2013 Metryka et al., 2020). Lead exposure throughout childhood has been linked to several abnormalities in the developing brain (Falkowska et al., 2015 Chibowska et al., 2016 Metryka et al., 2018), leading to a variety of cognitive impairments (Gilbert \& Lasley, 2002 Verina et al., 2007; Al-Saleh et al., 2009). Prenatal lead exposure has been linked to many neurodevelopmental diseases, including autism spectrum disorder (ASD (Amin, 2012 Saghazadeh \& Rezaei, 2017; El-Ansary et al., 2017; Smith et al., 2018; Chibowska et al., 2020), hyperactivity, emotional symptoms, and conduct disorder (Sioen et al., 2013), attentiondeficit hyperactivity disorder (ADHD) (Nicolescu et al., 2010 Hong et al., 2015). There is evidence that these impacts may last longer than childhood (Needleman et al., 1990 ;Cecil et al., 2008 ;Wright et al., 2008). There appears to be no threshold level below which lead causes no harm to the growing human brain (Sanders et al., 2009; Wani et al., 2015). Though no specific symptoms may be observed in children with high blood lead levels, blood samples from such infants exposed to hazardous levels of lead may be taken to detect the blood lead levels. This can also be discovered in the bone using specific x-rays of the finger, knee, or elbow (Agrawal, 2012).

To assess if lead exposure has occurred, the level of total lead in the blood can be measured. This test determines whether or not a person has recently been exposed to lead. Lead can be assessed in teeth or bones using x-ray techniques, but these procedures are not commonly available and only show long-term lead exposures. Lead exposure can also be assessed by detecting erythrocyte protoporphyrin (EP) levels in blood samples. EP is a component of red blood cells that is known to rise when there is a high level of lead in the blood. However, the EP level is insufficiently sensitive to identify children with high blood lead levels of less than 25 micrograms per deciliter $(\mathrm{g} / \mathrm{dL})$. These tests typically necessitate the use of specialized analytical equipment that is not widely available (Ettinger et al., 2020 ;CDC, 2020). A variety of laboratory procedures are available to detect blood lead concentrations in newborns
(Flanagan et al., 2008 ATSDR, 2020). The most frequent laboratory method is atomic absorption spectrometry. Anodic stripping voltammetry (ASV) and inductively coupled plasma mass spectrometry are two others (ICP-MS). Any method used to determine blood lead levels will be heavily influenced by its analytical capabilities, price, and technical requirements. These considerations influence the method selection choices.

Research efforts were able to establish that some chemical compounds could minimize the hazardous effects of lead due to the destructive effect of lead on the blood, brain, kidney, and other organs. Some of the research efforts include the role of exogenous hydrogen peroxide $\left(\mathrm{H}_{2} \mathrm{O}_{2}\right)$ in inducing tolerance to lead exposure ( $\mathrm{Li}$ et al., 2009), garlic and EDTA (Reckziegel et al., 2011), anti-oxidants like vitamin $\mathrm{C}$ and E (Hassan \& Jassim, 2010 El-Masry et al., 2011), nutrients containing methionine, taurine, zinc, ascorbic acid and glycine (Fan et al., 2009), supplements containing iron, calcium and zinc (Davuljigari \& Gottipolu, 2020), extracts of plant origin such as Rubia cordifolia (Maitra \& Satardekar, 2017), Moringa oleifera (Mahdy et al., 2012), Coriandrum sativum (Sharma et al., 2011). However, there has been a recent surge in interest in the use of medicinal plants, which provide significant therapeutic compounds that can help reduce the harmful effects of lead and other environmental toxins (Maitra \& Satardekar, 2017; Alves et al., 2006). Plant study has become more popular around the world, and a substantial body of information has been gathered that demonstrates the immense potential of medicinal herbs employed in diverse traditional systems. The protective properties of natural antioxidants have received more attention (Sánchez-Machado et al., 2006). Moringa oleifera is currently thought to be a source of dietary ingredients with biological and pharmacological activity that may have health advantages for humans.

The problem with chelating and other chemical agents now used to treat lead toxicity is that they cannot remove lead without damaging other cellular critical metals, and they can also cause toxicant redistribution and hepatic or renal failure, according to AL-Megrin et al., (2019). The use of medicinal plants as a therapeutic method, on the other hand, may 
reduce lead toxicity. For example, Abdel Moneim, (2016), found evidence that the nutritional components polyphenols, flavonoids, and organic acids in Indigofera oblongifolia extract protected liver tissue from lead acetate in a research.

Moringa oleifera is a perennial Indian tree that belongs to the Moringaceae family and is widely cultivated around the world due to its biological qualities (Khalil et al., 2020). Because the flowering, stem, and leaves of the tree offer therapeutic effects, all parts of the tree are essential (Abdel-Daim et al., 2019). Previous research has shown that the flower can be used as a tonic and to cure rheumatism and inflammation; the stems and seeds have hepatoprotective and anti-hypertensive actions; and the leaves can be used to fight microbial infections and to regulate hyperglycemia (El-Khadragy et al., 2018 Oguntibeju et al., 2020). Because of the high quantity of vitamins (A and C), antioxidants (anthocyanidins, glucosinolates, flavonoids, and phytosterols), and proteins, the leaves are consumed raw, boiled, or airdried to help with nutritional deficiencies (Kandeil et al., 2020). There are some signs that Moringa oleifera extract is safe. Human investigations employing up to a single dose of $50 \mathrm{~g}$ (William et al., 1993) or an $8 \mathrm{~g} /$ day dose for 40 days revealed no harmful effects (Kumari, 2010).

Although there is a wealth of research evidence demonstrating the negative effects of prenatal and childhood lead exposure on behavior, such as poor neuro-developmental outcomes, particularly in cognitive functioning (Gomaa et al., 2002 WHO, 2010), shortening of attention span, and disruption of behavior (Wright et al., 2008), and that these effects may persist beyond childhood (Needleman et al., 1990 Wright et al., 2008 Cecil et al., 2008), there is a scarcity of evidence on the presence of lead in the blood of prenatally exposed children. The majority of investigations have focused on maternal blood lead levels (Bellinger et al., 2005 WHO, 2010 Ettinger et al., 2020).

Lead poisoning and toxicity treatment and management is a worldwide concern. There appear to be no universally recognized therapeutic standards for lead toxicity. According to a World Health Organization report, many countries establish their own treatment standards for levels of lead exposure that they deem safe (WHO, 2013). The Center for Disease Control and Prevention (CDC) in the United States of America, for example, has suggested follow-up testing for both pregnant women and their newborn babies if the blood lead level is greater than $5 \mathrm{~g} / \mathrm{dl}$, and chelation therapy if the blood lead level is greater than $45 \mathrm{~g} / \mathrm{dl}$ (Ettinger et al., 2020). However, treatment of the lead poisoning and toxicity with chelating and other chemical agents has been reported to be inadequate (AL-Megrin et al., 2019), suggesting that the toxicity may be lessened by the use of medicinal plants as a therapeutic strategy (Abdel Moneim, 2016). There is evidence that extracts from different medicinal plants such as Indigofera oblongifolia, Moringa Oleifera etc. containing nutritional ingredients like polyphenols, flavonoids, and organic acids are known to protect tissues from lead toxicity (Rehman Ali et al., 2020). Although many researchers have reported the beneficial effects of Moringa oleifera in humans and animals, information regarding the utilization of the plant in lead remediation particularly at the prenatal stage of development is scanty.

This current study is therefore, aimed to evaluate the blood lead levels of Albino rat weanlings prenatally exposed to different doses of lead, relate it to the possible behavioral deficits associated with lead exposure and to investigate the remediation effect of Moringa oleifera leaf extract on the control of blood lead levels of prenatally exposed rat weanlings.

The following research questions were raised to provide answers to them.

1. What are the blood lead levels of Albino rat weanlings prenatally exposed to lead at different doses of 5, 8 and 10 micrograms per deciliter of lead?

(ii) What are the blood lead levels of Albino rat weanlings prenatally exposed to Moringa oleifera at different doses of 20 and 60 milligrams per kilogram body weight?

1. What are the blood lead levels of Albino rat weanlings prenatally exposed to combined doses of lead and Moringa oleifera at 5, 8, 


\section{EVALUATION OF BLOOD LEAD LEVELS (BLL) OF ALBINO RAT OFFSPRING (WEANLINGS) PRENATALLY EXPOSED TO LEAD AND MORINGA OLEIFERA}

and 10 micrograms per deciliter of lead and 20 and 60 milligrams per kilogram body weight of Moringa oleifera?

The following hypotheses were tested in determining the blood lead levels of prenatally exposed Albino rat weanlings to lead and the ameliorating effects of Moringa oleifera;

- Albino rat weanlings prenatally exposed to different doses of lead will have traces of the presence of lead in the blood

- Albino rat weanlings exposed to different doses of Moringa oleifera will have no traces of lead in the blood

- Albino rat weanlings exposed to combined doses of lead and Moringa oleifera at different doses will show less traces of lead in their blood.

\section{2 | METHODOLOGY}

\section{1 | Design}

The design for this study is a completely randomized design adopting a $3 \times 4$ factorial matrix. The independent variables are lead treatment which is at 4 levels; $5 \mu \mathrm{g}, 8 \mu \mathrm{g}, 10 \mu \mathrm{g}$ per kilogram body weight of rats, and no lead treatment (saline) and Moringa oleifera treatment which is at 3 levels; $20 \mathrm{mg}, 60 \mathrm{mg}$ per kilogram body weight of rats and no Moringa oleifera treatment (saline). The dependent variables are the blood lead levels of rat weanlings prenatally exposed to lead and Moringa oleifera.

\section{2 | Subjects}

Wister albino rats were used for this study. The rats fall into three main categories as follows

Category 1: - A total of 120 mature male Wister albino rats weighing between $220 \mathrm{~g}-250 \mathrm{~g}$ for the purpose of mating.

Category 2: - A total of 120 mature female albino rats weighing between $180 \mathrm{~g}-200 \mathrm{~g}$ randomly selected into the different experimental groups.
Category 3: - Offspring (Weanlings) of the Dams (female) albino rats in category 2 randomly selected from the different experimental groups of 5 micrograms, 8 micrograms, 10 micrograms of lead, 20 milligrams, 60 milligrams of Moringa oleifera and control groups (saline treatment).

Allocation of rats to the different cells was done by first acclimatizing the rats to the laboratory environment for two weeks, matching them according to gender and randomly allotting the rats to the different treatment groups represented in the cells below. It was ensured that the weight of rats in each cell was within the same range by random allotment of rats in the cells.

\section{Table 1 Factorial Design Cells}

\begin{tabular}{|c|c|c|c|}
\hline & Moringa oleifera & & \\
\hline Lead & $20 \mathrm{mg}$ & $60 \mathrm{mg}$ & $\begin{array}{ll} & \text { B3 } \\
\text { Omg } & \end{array}$ \\
\hline $\begin{array}{ll} & \mathrm{Al} \\
0 \mu \mathrm{g} & \end{array}$ & ${ }_{\mathrm{AlB} 1}^{1}$ & $\mathrm{AlB} 2^{2}$ & ${ }^{3}{ }^{3}$ \\
\hline $5 \mu \mathrm{g}$ & $\mathrm{A} 2 \mathrm{~B} 1^{4}$ & $\mathrm{~A} 2 \mathrm{~B} 2^{5}$ & $\mathrm{~A} 2 \mathrm{~B} 3^{6}$ \\
\hline $\begin{array}{ll} & A 3 \\
8 \mu g & \end{array}$ & $\mathrm{~A}^{7}{ }^{7}$ & A3B2 ${ }^{8}$ & A3B3 ${ }^{9}$ \\
\hline $10 \mu \mathrm{g}$ & $\mathrm{A} 4 \mathrm{Bl}$ & $\mathrm{A} 4 \mathrm{~B} 2{ }^{11}$ & A4B3 ${ }^{12}$ \\
\hline
\end{tabular}

Cell 1 - 20mg/kg body weight Moringa oleifera

Cell 2 - 60mg/kg body weight Moringa oleifera

Cell 3 - Control group (No Moringa and Lead), Saline treatment

Cell 4 - Combined $5 \mu \mathrm{g} / \mathrm{kg}$ lead and $20 \mathrm{mg} / \mathrm{kg}$ Moringa oleifera

Cell 5 - Combined $5 \mu \gamma \mathrm{g} / \mathrm{kg}$ lead and $60 \mathrm{mg} / \mathrm{kg}$ Moringa oleifera

Cell $6-5 \mu \mathrm{g} / \mathrm{kg}$ lead only

Cell 7 - Combined $8 \mu \mathrm{g} / \mathrm{kg}$ lead and $20 \mathrm{mg} / \mathrm{kg}$ Moringa oleifera

Cell 8 - Combined $8 \mu \mathrm{g} / \mathrm{kg}$ lead and $60 \mathrm{mg} / \mathrm{kg}$ Moringa oleifera

Cell $9-8 \mu \mathrm{g} / \mathrm{kg}$ lead only

Cell 10 - Combined $10 \mu \mathrm{g} / \mathrm{kg}$ lead and $20 \mathrm{mg} / \mathrm{kg}$ Moringa oleifera

Cell 11 - Combined $10 \mu \mathrm{g} / \mathrm{kg}$ lead and $60 \mathrm{mg} / \mathrm{kg}$ Moringa oleifera

Cell $1210 \mu \mathrm{g} / \mathrm{kg}$ lead only 


\section{3 | Housing of Rats}

The subjects (Wister Albino rats) were raised and maintained in the experimental animal laboratory of the Faculty of Veterinary Medicine, University of Ibadan, in a regular day-night cycle (12: 12-hour light dark cycle) in RCI North Kent Plastic cages. The RCI plastic cages have dimension of $56 \mathrm{~cm} \mathrm{x}$ $40 \mathrm{~cm} \times 18 \mathrm{~cm}$. The rats were housed in twos - one male and one female until 3 days when conception was assumed to have taken place. The animals were fed with Mouse cubes (a standard laboratory rat feed) and water. All the observations were carried out between 9:00 am to 2:00 pm. The experimental protocols were approved by the UI/UCH Institutional Ethics Committee Number UI/UCH/EC/15/0040.

\section{4 | Equipment / Materials}

The following instruments were used for the study:

1. Rat cages: These were RCI North Kent plastic cages measuring $56 \mathrm{~cm} \times 40 \mathrm{~cm} \times 18 \mathrm{~cm}$ for breeding and general housing of subjects in groups and RI North Kent plastic cages measuring $45 \mathrm{~cm}$ x $27 \mathrm{~cm} \mathrm{x}$ $40 \mathrm{~cm}$ for observation purposes.

2. Two weighing balances were used for the study. They were:

i. A Chatillon, New York. N.Y. 11415 weighing balance with capacity of $500 \times 2 \mathrm{~g}$ this was used for weighing rats, and

ii. A computerized Metler-Toledo weighing balance with a maximum capacity of $5 \mathrm{~kg}$ and minimum capacity of $0.01 \mathrm{mg}$. This was used for weighing lead, Moringa oleifera and other chemical substances that require very sensitive weights because of minute quantity involved.

3. A $250 \mathrm{ml}$ graduated measuring cylinder was employed for measuring saline used to dilute the substances.

4. Water bottles with stainless steel tunnels were used to provide drinking water for the subjects.

5. An oral cannula was used for oral administration of lead, Moringa oleifera and saline.

6. Disposable $5 \mathrm{ml}$ and $2 \mathrm{ml}$ syringes and needles were employed for the collection of lead, Moringa oleifera and saline during dilution process.

7. Standard animal feed (mouse cubes) was used for feeding the subjects.

8. Substances for the experiment were lead, Moringa oleifera and saline.

9. Atomic Absorption Spectrophotometer was used to determine blood lead levels of weanlings of the rats.

\section{5 | Experimental Procedure}

The experiment started with random assignment of female rats into individual cages for the purpose of mating. The male rats also were individually and randomly assigned into the individual cages containing the female rats on the day of commencement of the experiment. The male rats were only used for the purpose of mating the female rats for three days only within which it was expected that the female rats have mated. The female rats on the other hand were weighed and randomly assigned into the following treatment groups:

1. Control group with saline treatment

2. 5 micrograms per deciliter / $\mathrm{kg}$ body weight lead treatment group.

3. 8 micrograms per deciliter / $\mathrm{kg}$ body weight lead treatment group

4. 10 micrograms per deciliter / $\mathrm{kg}$ body weight lead treatment group.

5. 20 milligrams per kilogram body weight Moringa oleifera treatment group.

6. 60 milligrams per kilogram body weight Moringa oleifera treatment group.

7. Combined 5 microgram per kilogram body weight of lead and 20 milligrams per body weight of Moringa oleifera.

8. Combined 8 microgram per kilogram body weight of lead and 60 milligrams per kilogram body weight of Moringa oleifera.

9. Combined 10 microgram per kilogram body weight of lead and 60 milligrams per kilogram body weight of Moringa oleifera.

10. Combined 5 microgram per kilogram body weight of lead and 60 milligrams per kilogram body 


\section{EVALUATION OF BLOOD LEAD LEVELS (BLL) OF ALBINO RAT OFFSPRING (WEANLINGS) PRENATALLY EXPOSED TO LEAD AND MORINGA OLEIFERA}

weight of Moringa oleifera.

11. Combined 8 microgram body weight of lead and 20 milligram body weight of Moringa oleifera.

12. Combined 10 microgram body weight of lead and 20 milligrams per kilogram body weight of Moringa oleifera.

Each treatment group comprised ten dams.

Lead was prepared into fresh solutions containing $5 \mu \mathrm{g} / \mathrm{dl} / \mathrm{kg}$ body weight, $8 \mu \mathrm{g} / \mathrm{dl} / \mathrm{kg}$ body weight and $10 \mu \mathrm{g} / \mathrm{d} 1 / \mathrm{kg}$ body weight concentration by diluting a stock solution of lead into one million parts per million (PPM). A stock solution of Moringa oleifera isolate was also prepared into $20 \mathrm{mg} / \mathrm{kg}$ and $60 \mathrm{mg} / \mathrm{kg}$ concentration by the dilution into one thousands part per million (PPM). The dams were then given oral administration of lead with the help of the oral canula. They were allowed a period of 30 minutes before food and water was restored to them to ensure that the action of the drug has begun. On the third day of the experiment, the male rats were removed leaving only the females.

The procedure of treatment was repeated for 16 days of the gestation period. This was to ensure:

a. That the action of the drug covers three trimesters of the dam's gestational period which normally spans for duration of $21+1$ day.

b. Dams will not be given drugs on the days of parturition. On this basis it will be claimed that treatment covers most days of gestation.

The dams were only weighed and observed from day 17 to parturition without treatment. At parturition, the litter, size and the mean birth weight was taken at the nearest experimental time. The offspring were allowed to breast feed for 21 days after which they were weaned. The next stage of the experiment continued with the offspring (weanlings) which were gathered into groups according to their experimental groupings. Blood samples of each weanling according to their experimental groups were collected using EDTA bottles. The blood samples were analyzed for the presence of lead to determine the blood lead levels of the rat weanlings using the Atomic Absorption Spectrophotometer.

\section{3 | RESULTS}

The findings of this research on the assessment of blood levels of Albino rat weanlings prenatally exposed to lead and Moringa oleifera are reported in accordance with the hypotheses proposed. The obtained data was subjected to Randomized Block Analysis of Variance (ANOVA), descriptive statistics of mean and standard deviation, and graphical representation.

Table 2: Summary of Factorial ANOVA table showing Comparison of the blood- lead levels of rat weanlings prenatally exposed to lead and Moringa oleifera

\begin{tabular}{lcclll}
\hline & Sum of Squares & df & Mean Square & F & Sig. \\
\hline Between & 8.099 & 11 & .736 & 102.338 & .000 \\
Groups & & 108 & .007 & & \\
Within Groups.777 & 119 & & & \\
Total & 8.876 & & & & \\
\hline
\end{tabular}

In Table 2, ANOVA analysis of the blood- lead levels of rat weanlings prenatally exposed to lead shows that there was a significant difference between rat weanlings prenatally exposed to Moringa Oleifera in combination with lead, rat weanlings exposed to lead only and rat weanlings exposed to Moringa Oleifera only $(\mathrm{F}(11,108)=102.34, \mathrm{p}<.001)$. Rat weanlings prenatally exposed to higher lead doses had more lead in their blood compared to rat weanlings exposed to Moringa Oleifera in combination with lead, rat weanlings exposed to lead only and rat weanlings exposed to Moringa Oleifera only.

Table 3. Descriptive and scheffe post hoc comparison values of the blood lead levels of rat weanlings prenatally exposed to different doses of lead and Moringa oleifera

\begin{tabular}{|c|c|c|c|c|c|c|c|c|c|c|c|c|c|}
\hline & & 1 & 2 & 3 & 4 & 5 & 6 & 7 & 8 & 9 & 10 & 11 & 12 \\
\hline 1 & $10 \mu \mathrm{g}$ lead & - & & & & & & & & & & & \\
\hline & & $.18^{\star}$ & - & & & & & & & & & & \\
\hline 2 & & & & & & & & & & & & & \\
\hline & $\begin{array}{l}10 \mu \mathrm{g} \\
\text { lead } / 60 \mathrm{mg}\end{array}$ & $.25^{*}$ & .07 & & & & & & & & & & \\
\hline 3 & moringa & & & & & & & & & & & & \\
\hline & $20 \mathrm{mg}$ & $.75^{\star}$ & $.57^{\star}$ & $.50^{\star}$ & & & & & & & & & \\
\hline 4 & moringa & & & & & & & & & & & & \\
\hline 5 & $5 \mu \mathrm{g}$ lead & $.23^{*}$ & .05 & -.02 & $-.52^{+}$ & & & & & & & & \\
\hline 6 & $\begin{array}{l}5 \mu \mathrm{g} \text { lead } / 20 \\
\mathrm{mg} \text { moringa }\end{array}$ & .25 & .07 & 0.00 & -.50 & .02 & & & & & & & \\
\hline & $5 \mu \mathrm{g}$ lead $/ 60$ & $.60^{*}$ & $.42^{*}$ & $.35^{*}$ & $-.15^{*}$ & $.37^{*}$ & $.35^{*}$ & & & & & & \\
\hline 8 & $\begin{array}{l}\text { mg moringa } \\
60 \mathrm{mg} \\
\text { moringa }\end{array}$ & $.75^{*}$ & $.57^{*}$ & $.50^{*}$ & 0.00 & $.52^{*}$ & $.50^{*}$ & $.15^{*}$ & & & & & \\
\hline 9 & $8 \mu \mathrm{g}$ lead & $.14^{*}$ & -.04 & $\begin{array}{l}- \\
.11^{*}\end{array}$ & $-.61^{*}$ & -.09 & $-11^{*}$ & $\begin{array}{l}- \\
.46\end{array}$ & $-61^{\circ}$ & & & & \\
\hline 10 & $\begin{array}{l}8 \mu g \text { lead } / 20 \\
\text { mg moringa }\end{array}$ & $.18^{\star}$ & 0.00 & -.07 & $-.57^{*}$ & -.05 & -.07 & $.42^{*}$ & $-57^{*}$ & .04 & & & \\
\hline 11 & $\begin{array}{l}8 \mu \mathrm{g} \\
\text { lead/60mg } \\
\text { moringa }\end{array}$ & $.25^{*}$ & .07 & 0.00 & $-.50^{*}$ & .02 & 0.00 & -.35 & - & $.11^{*}$ & .07 & & \\
\hline 12 & Control & $.75^{*}$ & $.57^{*}$ & $.50^{*}$ & 0.00 & $.52^{*}$ & $.50^{*}$ & $.15^{*}$ & 0.00 & $.61^{*}$ & $.57^{*}$ & $.50^{*}$ & \\
\hline & Mean & 0.75 & 0.57 & 0.50 & 0.00 & 0.52 & 0.50 & 0.15 & 0.00 & 0.61 & 0.57 & 0.50 & 0.00 \\
\hline & S.D & 0.08 & 0.07 & 0.00 & 0.00 & 0.04 & 0.00 & 0.24 & 0.00 & 0.11 & 0.05 & 0.00 & 0.00 \\
\hline
\end{tabular}




\section{MEERP LTD}

*mean comparison significantly different at $\mathbf{0 . 0 5}$ of significance.

Table 4. Summary of mean scores of blood lead levels of rat weanlings prenatally exposed to different doses of lead and Moringa oleifera

\begin{tabular}{|c|c|}
\hline & Mean \pm S.D \\
\hline $5 \mu \mathrm{gLead}$ & $0.52 \pm 0.04^{c}$ \\
\hline $8 \mu \mathrm{g}$ lead & $0.61 \pm 0.11^{\mathrm{d}}$ \\
\hline $10 \mu \mathrm{g}$ lead & $0.75 \pm 0.08^{d}$ \\
\hline 20mg moringa & $0.00 \pm 0.00^{\mathrm{a}}$ \\
\hline $60 \mathrm{mg}$ moringa & $0.00 \pm 0.00^{\mathrm{a}}$ \\
\hline $5 \mu \mathrm{g}$ lead $/ 20 \mathrm{mg}$ moringa & $0.5 \pm 0.01^{c}$ \\
\hline $8 \mu \mathrm{g}$ lead$/ 20 \mathrm{mg}$ moringa & $0.57 \pm 0.05^{\mathrm{cd}}$ \\
\hline $10 \mu \mathrm{g}$ lead $/ 20 \mathrm{mg}$ moringa & $0.57 \pm 0.07^{\mathrm{cd}}$ \\
\hline $5 \mu \mathrm{g}$ lead/60 mg moringa & $0.15 \pm 0.24^{b}$ \\
\hline $8 \mu \mathrm{g}$ lead $/ 60 \mathrm{mg}$ moringa & $0.5 \pm 0.00^{c}$ \\
\hline $10 \mu \mathrm{g}$ lead $/ 60 \mathrm{mg}$ moringa & $0.5 \pm 0.00^{c}$ \\
\hline Control & $0.00 \pm 0.00^{\mathrm{a}}$ \\
\hline
\end{tabular}

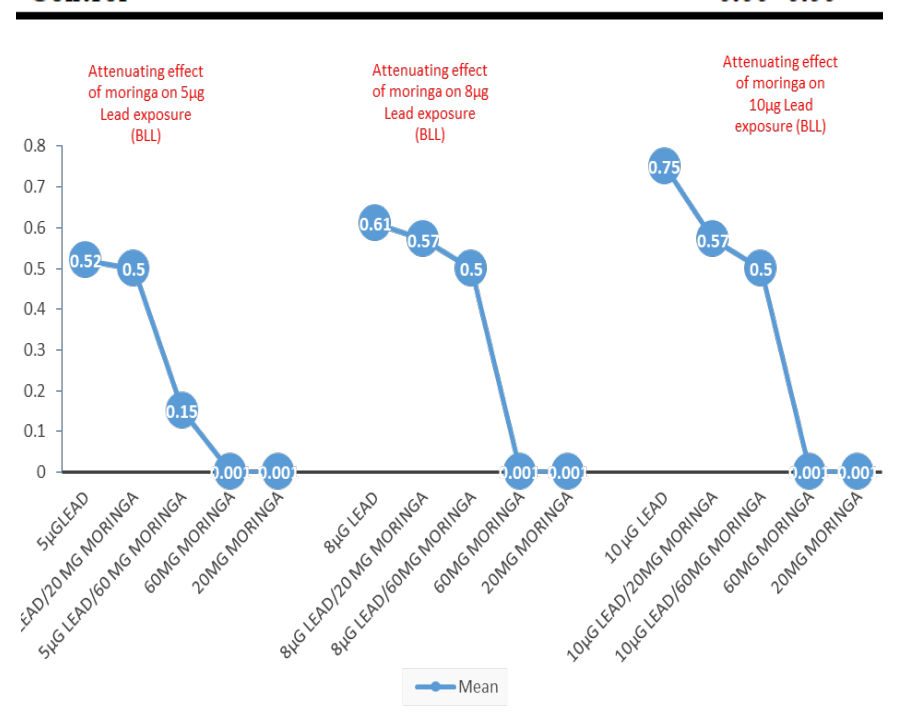

Blood Lead Level of Prenatally Exposed Rats

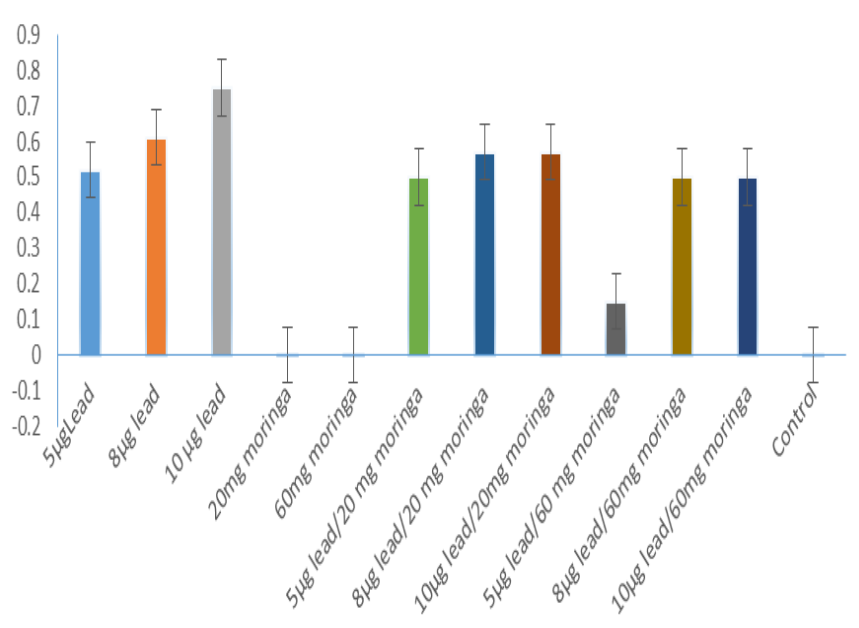

Fig1: Blood Lead Level of Prenatally Exposed Rats

Fig.1 shows that rat weanlings exposed to higher doses of lead $(10 \mu \mathrm{g}$ and $8 \mu \mathrm{g})$ had more lead in their blood compared to rat weanlings exposed to Moringa oleifera in combination with lead, rat weanlings exposed to lead only and rat weanlings exposed to Moringa oleifera only. This confirmed that there was significant amount of lead in the blood of the prenatally exposed rat weanlings.

Analysis of the blood lead levels of rat weanlings prenatally exposed to different doses of lead and Moringa oleifera in Table 2 shows that there was a significant difference between blood lead levels of rat weanlings prenatally exposed to Moringa oleifera in combination with lead, lead only and Moringa oleifera only.

The first hypothesis which stated that Albino rat weanlings prenatally exposed to different doses of lead will have traces of the presence of lead in the blood compared to weanlings who were not exposed was confirmed. In Table 3 and 4, the pair wise comparison reveals that the rats in the control group $(=0.00)$ which were not exposed to lead significantly $(p<.05)$ demonstrated no traces of lead in their blood compared to weanlings exposed to lead $(10 \mu \mathrm{g}$ lead $=(=0.75) ; 5 \mu \mathrm{g}$ lead $=(=0.52)$; $8 \mu \mathrm{g}$ lead $=(=0.61))$.

The second hypothesis which stated that Albino rat weanlings exposed to different doses of Moringa oleifera will have no traces of lead in the blood was also supported. Pair wise comparison also demon-strated that the rat weanlings in the $20 \mathrm{mg}$ Moringa oleifera $(=0.00), 60 \mathrm{mg}$ moringa oleifera $(=0.00)$ experimental groups whose mothers were not ex-posed to lead significantly $(p<.05)$ demonstrated no traces of lead in their blood compared to weanlings exposed to lead (10 $\mu \mathrm{g}$ lead $=(=0.75) ; 5 \mu \mathrm{g}$ lead $=(=0.52) ; 8 \mu \mathrm{g}$ lead $=$ $(=0.61))$. 


\section{EVALUATION OF BLOOD LEAD LEVELS (BLL) OF ALBINO RAT OFFSPRING (WEANLINGS) PRENATALLY EXPOSED TO LEAD AND MORINGA OLEIFERA}

The third hypothesis which stated that Albino rat weanlings exposed to combined doses of lead and Moringa oleifera at different doses will show less traces of lead in their blood was also supported. Rat weanlings prenatally exposed to higher doses of lead had more lead in their blood compared to rat weanlings exposed to Moringa oleifera in combination with lead, lower doses of lead only and Moringa oleifera only. The mean comparison significantly show that rat weanlings exposed to higher doses of lead had more lead in their blood compared to rat weanlings exposed to Moringa oleifera in combination with lead, lower doses of lead only and Moringa oleifera only.

\section{4 | DISCUSSION}

This study was primarily designed to investigate the blood lead levels (BLL) of rat offspring (weanlings) prenatally exposed to single and combined doses of lead and Moringa oleifera. Blood Lead Level (BLL) of the prenatally exposed rat weanlings was analysed by the researcher using Atomic Absorption Spectrophotometer to investigate the presence of lead in the blood of prenatally exposed rat weanlings. Different levels of lead were detected in the blood of the weanlings according to their levels of prenatal exposure to lead and Moringa oleifera. The result shows a significant difference between blood lead levels of rat weanlings prenatally exposed to lead in combination to Moringa oleifera, (rat weanlings exposed to lead only and rat weanlings exposed to Moringa oleifera only $(\mathrm{F}(11,108)=102.34$, $\mathrm{p}<.001)$ ). Rat weanlings prenatally exposed to higher doses of lead had more lead in their blood compared to rat weanlings exposed to Moringa oleifera in combination with lead, and rat weanlings exposed to Moringa oleifera only. The mean comparison significantly show that rat weanlings exposed to higher doses of lead had more lead in their blood compared to rat weanlings exposed to Moringa oleifera in combination with lead, and rat weanlings exposed to Moringa oleifera only $(10 \mu \mathrm{g}$ lead $(=0.75) ; 10 \mu \mathrm{g}$ lead/60mg Moringa $(=0.5) ; 60 \mathrm{mg}$ Moringa $(=0.0)$.

According to some research, there is a possible physiologic mobilization of bone lead storage dur- ing pregnancy and lactation, making unborn fetuses more susceptible to increasing lead concentrations from pregnant women (Ettinger et al., 2020). According to Markowitz (2000), lead that has been deposited in the mother's bones for years is released into the blood during pregnancy due to the metabolic stress. Throughout pregnancy, lead easily transfers from maternal to baby circulation, and the infant's blood lead levels becomes nearly comparable to that of the mother (Markowitz, 2000). According to Bellinger, (2008), Lead moves readily through passive diffusion from mother to fetus indicating a possibility of the occurrence of prenatal lead exposure as seen from the findings of this research. There are research evidences that Lead can cross into the baby (WHO, 2010 Ettinger et al., 2020 Bellinger, 2008). Although it is unknown how early lead can reach a growing baby during pregnancy, some reports have shown lead in a developing fetus as early as the 13th week of pregnancy. (Ladele et al., 2019 Ettinger et al., 2020).

Agrawal, (2012), discovered that lead is strongly attached to red blood cells, boosting the transfer from maternal circulation to the fetus via the placenta, and that the placental transfer occurs as early as the twelfth week of gestation. Previous animal studies of brain lead content have revealed that the blood-brain barrier is more vulnerable to lead during pregnancy, becoming more effective during weaning and much more so following weaning (Rossouw et al., 1987 Toews et al., 1978). Even at very low levels of exposure, the developing human brain is particularly vulnerable to lead, and once in the infant, lead can permeate the immature blood-brain barrier and enter the developing brain (Lidsky \& Schneider, 2006 Shell, 2016).

Lead can be passed to the unborn by young women who live in lead contaminated homes or who were lead poisoned as children, according to Vigeh et al., (2011). As a result, there is a substantial relationship between maternal and umbilical cord blood lead levels, demonstrating that lead is transferred from mother to fetus (Torabi et al., 2018). According to research, lead accumulates and is stored in bone for decades, and these bone lead deposits may pose a risk to women of reproductive age long after their lead exposure has ended (Agrawal, 2012). As a result, 
lead can enter the fetus from the environment (exogenous lead) or through the bones (endogenous lead). In addition to prenatal lead transmission, lead levels in breast milk increase with maternal blood lead levels, increasing the likelihood of newborn blood lead (Weitzman \& Kursmark, 2009). Furthermore, Cormick et al., (2019), observed that high calcium intake may reduce pregnancy induced increases in maternal blood lead concentrations by reducing maternal bone resorption or demineralization during pregnancy and the consequent flow of lead from the bone to the fetus. Ladele et al., (2019), discovered a high positive connection between maternal and umbilical cord blood lead levels in a study. This conclusion implies that maternal blood lead levels, as reported in this work, are a robust indicator of the presence of lead in the blood of prenatally exposed rats. Similar investigations found a direct link between maternal and umbilical cord blood lead levels.

The results of this research revealed that rat weanlings prenatally treated to Moringa oleifera alone or as a control had no trace of lead in their blood. However, rat weanlings treated to a combination dose of $60 \mathrm{mg} / \mathrm{kg}$ Moringa oleifera $/ 10 \mathrm{~g}$ lead showed less trace of lead presence than those subjected to a high dose of $10 \mathrm{~g} / \mathrm{kg}$ lead alone. The findings of this research is suggestive of the ameliorative effects of Moringa oleifera on lead poisoning effect. The submissions of Jiraungkoorskul \& Jiraungkoorskul, (2016) that Moringa oleifera in its different forms, fruit, seed, leaf, flower, bark, and root, have been extensively employed in traditional medicine, including the decrease of heavy metal toxicity, confirm the conclusions of this study. Moringa oleifera has been shown to have a variety of chemical compounds with biological activities such as metal concentration depletion and antioxidant capabilities that have the ability to reduce oxidative stress caused by heavy metals. Sharayu \& Asmita, (2017) showed in a similar investigation that the leaves and seeds of Moringa Oleifera exhibit anti-metal toxicity properties.

The ameliorative effect of Moringa oleifera in its many forms on lead toxicity is undeniable, as proven by several research findings. (Owolabi, et al., 2012 Mohamed et al., 2020 Omóbòwálé et al., 2020 Farid \& Hegazy, 2020). This could be attributable to Moringa oleifera's chemical composition. Scientific evidence supports the medical use of Moringa oleifera as claimed by numerous cultures and groups. Moringa oleifera has been discovered to contain a wide range of vital nutrients, including vitamins, minerals, and amino acids (Kasolo et al., 2010 Fahey, 2016 Abd El-Hack et al., 2018). Moringa oleifera leaves are thought to contain significant levels of vitamin $\mathrm{C}$, calcium, potassium, and protein. Moringa oleifera is a good source of natural antioxidants since it contains a variety of antioxidant components such as flavonoids, ascorbic acid, carotenoids, and phenolics. (Dillard \& Bruce German, 2000 NiziołŁUkaszewska et al., 2020).

Moringa oleifera's ameliorative effect on lead toxicity may be linked to the high calcium content of Moringa oleifera leaves. Some studies have examined reductions in blood lead concentrations in calcium supplemented women and found that calcium supplementation may be useful in lowering blood lead levels in pregnant women with elevated lead levels (Ettinger et al., 2009 Ladele, Fajolu, et al., 2019). Lead absorption is known to increase significantly with lack of calcium consumption particularly in pregnancy. Researches with humans and experimental animals have shown that diets low in calcium can enhance gastrointestinal lead absorption in humans and experimental animals (Ettinger et al., 2007 Dubey \& Patel, 2018). On the contrary, diets that are rich in calcium reduce lead absorption and are known to provide additional protection against lead toxicity Ettinger et al., 2007).

\section{5 | CONCLUSIONS}

This study highlighted prenatal exposure of lead and its effect on the offspring. Blood Lead Levels of the offspring was particularly investigated with a strong evidence that prenatal exposure to lead increases the incidence of lead poisoning of the fetus. This was exhibited by the presence of lead in the blood of the offspring prenatally exposed to lead. Lead as an environmental toxin has the ability to permeate the placenta and is especially toxic to the growing foetus. The heavy metal is not filtered by the placenta from mother to child and is directly deposited in 


\section{EVALUATION OF BLOOD LEAD LEVELS (BLL) OF ALBINO RAT OFFSPRING (WEANLINGS) PRENATALLY EXPOSED TO LEAD AND MORINGA OLEIFERA}

growing foetal tissues. This study also concluded that Moringa oleifera, a medicinal plant has the ability to ameliorate the toxic effect of lead at all doses and on a dose dependent manner. It is recommended that given the toxic effect of lead on the fetus, pregnant women are advised to stay away from environments prone to lead inhalation or ingestion considering the implications brain development and behavior.

\section{ACKNOWLEDGEMENTS}

The authors wish to express gratitude to the experimental animal laboratory of Faculty of Veterinary Medicine University of Ibadan, Nigeria for making their Laboratory available for the study. The Authors wish to state that no funding was received for the study from any agency, the study was self-sponsored by all the authors.

\section{CONFLICT OF INTEREST}

The Authors hereby declare that there is no conflict of interest in this study.

\section{AUTHORS CONTRIBUTION}

J. I. Osuh conceptualized the study, designed the protocols, did some of the literature search and supervised the data collection for the whole study

A. M. Sunmola supervised the study and read the manuscript.

S. K. Balogun co supervised the work and read the manuscript.

A. A. Ishola did some of the literature search and analyzed the data

Finally, All the authors read through and approved the final copy of the manuscript.

\section{Acknowledgement}

The Authors did not receive any funds from any funding agency for this study. We wish to state that the study was self-sponsored by all the authors.

\section{Conflict of Interest}

The Authors unanimously declare that there is no conflict of interest in this study.

ETHICAL APPROVAL
All authors hereby declare that "Principles of laboratory animal care" (National Research Council (2011) GUIDE FOR LABORATORY ANIMALS FOR THE CARE AND USE OF ANIMALS (8ed) were followed, as well as specific national laws where applicable. All experiments have been examined and approved by the appropriate ethics committee" as referenced above.

\section{REFERENCES}

1. Abd El-Hack, M. E., Alagawany, M., Elrys, A. S., Desoky, E. S. M., Tolba, H. M. N., Elnahal, A. S. M., Elnesr, S. S., \& Swelum, A. A. (2018). Effect of forage moringa oleifera 1. (moringa) on animal health and nutrition and its beneficial applications in soil, plants and water purification. In Agriculture (Switzerland) (Vol. 8, Issue 9, p. 145). MDPI AG. https://doi.org/1 0.3390 /agriculture 8090145

2. Abdel-Daim, M. M., Khalil, S. R., Awad, A., Zeid, E. H. A., Abd El-Aziz, R., \& El-Serehy, H. A. (2019). Ethanolic Extract of Moringa oleifera Leaves Influences NF- $\kappa \mathrm{B}$ Signaling Pathway to Restore Kidney Tissue from CobaltMediated Oxidative Injury and Inflammation in Rats. Biomedical Pharmacotherapy, 109(16881697). https://doi.org/10.3390/nu12041031

3. Abdel Moneim, A. E. (2016). Indigofera oblongifolia Prevents Lead Acetate-Induced Hepatotoxicity, Oxidative Stress, Fibrosis and Apoptosis in Rats. PLOS ONE, 11(7), e0158965. https://doi.org/10.1371/journal.pone .0158965

4. Abushady, M. M., Fathy, H. A., Fathy, G. A., Abd El Fatah, S., Ali, A., \& Abbas, M. A. (2017). Blood lead levels in a group of children: the potential risk factors and health problems. Jornal de Pediatria, 93(6), 619-624. https://doi. org/10.1016/j.jped.2016.12.006

5. Agency for Toxic Substance and Disese Registry (ATSDR). (2020). Toxicological profile for lead. https://doi.org/10.15620/cdc:95222 
6. Agrawal, A. (2012). Toxicity and Fate of Heavy Metals with Particular Reference to Developing Foetus. Advances in Life Sciences, 2012(2), 29-38. https://doi.org/10.5923/j.als.20120202. 06

7. AL-Megrin, W. A., Alkhuriji, A. F., Yousef, A. O. S., Metwally, D. M., Habotta, O. A., Kassab, R. B., Abdel Moneim, A. E., \& El-Khadragy, M. F. (2019). Antagonistic Efficacy of Luteolin against Lead Acetate Exposure-Associated with Hepatotoxicity is Mediated via Antioxidant, Anti-Inflammatory, and Anti-Apoptotic Activities. Antioxidants, 9(1), 10. https://doi.o $\mathrm{rg} / 10.3390 /$ antiox 9010010

8. Al-Megrin, W. A., Alkhuriji, A. F., Yousef, A. O. S., Metwally, D. M., Habotta, O. A., Kassab, R. B., Moneim, A. E. A., \& El-Khadragy, M. F. (2020). Antagonistic efficacy of luteolin against lead acetate exposure-associated with hepatotoxicity is mediated via antioxidant, antiinflammatory, and anti-apoptotic activities. Antioxidants, 9(1). https://doi.org/10.3390/antiox9 010010

9. Al-Quraishy, S., Dkhil, M., Ibrahim, S., \& Abdel Moneim, A. (2016). Neuroprotective potential of Indigofera oblongifolia leaf methanolic extract against lead acetate-induced neurotoxicity. Neural Regeneration Research, 11(11), 1797. https://doi.org/10.4103/1673-5374.1947 49

10. Al-Saleh, I., Nester, M., Mashhour, A., Moncari, L., Shinwari, N., Mohamed, G. E. D., \& Rabah, A. (2009). Prenatal and postnatal lead exposure and early cognitive development: Longitudinal study in Saudi Arabia. Journal of Environmental Pathology, Toxicology and Oncology, 28(4), 283-302. https://doi.org/10.1615 /JEnvironPatholToxicolOncol.v28.i4.40

11. Aladaileh, S. H., Khafaga, A. F., Abd El-Hack, M. E., Al-Gabri, N. A., Abukhalil, M. H., Alfwuaires, M. A., Bin-Jumah, M., Alkahtani, S., Abdel-Daim, M. M., Aleya, L., \& Abdelnour, S. (2020). Spirulina platensis ameliorates the sub chronic toxicities of lead in rabbits via anti-oxidative, anti- inflammatory, and immune stimulatory properties. Science of the Total Environment, 701. https://doi.org/10.1016/j.scitot env.2019.134879

12. Alves, L. C., Glover, C. N., \& Wood, C. M. (2006). Dietary Pb Accumulation in Juvenile Freshwater Rainbow Trout (Oncorhynchus mykiss). Toxicology, 51, 285-298. https://doi.o $\mathrm{rg} / 10.1007 / \mathrm{s} 00244-005-0212-7$

13. Amin, O. (2012). P-253 - Heavy metals and and trace elements in hair and urine of a sample of arab children with autistic spectrum disorder. European Psychiatry, 27(4), 1. https://doi.org/1 0.1016/s0924-9338(12)74420-6

14. ATSDR (Agency for Toxic Substances and Disease Registry). (2020). Toxicological profile for lead. https://doi.org/10.15620/cdc:95222

15. Aziz, F. M., Maulood, I. M., \& Chawsheen, M. A. H. (2012). Effects of melatonin, vitamin Cand $\mathrm{E}$ alone or in combination on lead-induced injury in liver and kidney organs of rats. In IOSR Journal of Pharmacy (Vol. 2). www.ios rphr.org

16. Baranowska-Bosiacka, I., Stru, L., Zy'nskazy'Zy'nska, ', Gutowska, I., Machalí Nska, A., Kolasa, A., Kłos, P., Czapski, G. A., Kurzawski, M., Prokopowicz, A., Marchlewicz, M., Safranow, K., Machalí Nski F, B., Wiszniewska, B., \& Chlubek, D. (2013). Perinatal exposure to lead induces morphological, ultrastructural and molecular alterations in the hippocampus. Toxicology, 303, 187-200. https://doi.org/10.1 016/j.tox.2012.10.027

17. Bellinger, D. C. (2008). Very low lead exposures and children's neurodevelopment. In Current Opinion in Pediatrics (Vol. 20, Issue 2, pp. 172-177). Curr Opin Pediatr. https://doi.org/10 .1097/MOP.0b013e3282f4f97b

18. Bellinger, D. C., Hu, H., Kalaniti, K., Thomas, N., Rajan, P., Sambandam, S., Ramaswamy, P., \& Balakrishnan, K. (2005). A pilot study of blood lead levels and neurobehavioral function 
in children living in Chennai, India. International Journal of Occupational and Environmental Health, 11(2), 138-143. https://doi.org /10.1179/oeh.2005.11.2.138

19. CDC (Centers for Disease Control and Prevention. (2012). Low Level Lead Exposure Harms Children: A Renewed Call for Primary Prevention.

20. CDC (Centers for Disease Control and Prevention. (2020). Childhood Lead Poisoning Prevention Program | CDC. https://www.cdc.gov/nceh /lead/default.htm

21. Cecil, K. M., Brubaker, C. J., Adler, C. M., Dietrich, K. N., Altaye, M., Egelhoff, J. C., Wessel, S., Elangovan, I., Hornung, R., Jarvis, K., \& Lanphear, B. P. (2008). Decreased Brain Volume in Adults with Childhood Lead Exposure. PLoS Medicine, 5(5), e112. https://doi.or $\mathrm{g} / 10.1371$ /journal.pmed.0050112

22. Chen, A., Cai, B., Dietrich, K. N., Radcliffe, J., \& Rogan, W. J. (2007). Lead exposure, IQ, and behavior in urban 5- to 7-year-olds: Does lead affect behavior only by lowering IQ? Pediatrics, 119(3). https://doi.org/10.1542/peds.200 6-1973

23. Chibowska, K., Baranowska-Bosiacka, I., Falkowska, A., Gutowska, I., Goschorska, M., \& Chlubek, D. (2016). Effect of lead $(\mathrm{Pb})$ on inflammatory processes in the brain. In International Journal of Molecular Sciences (Vol. 17, Issue 12). MDPI AG. https://doi.or $\mathrm{g} / 10.3390 / \mathrm{ijms} 17122140$

24. Chibowska, K., Korbecki, J., Gutowska, I., Metryka, E., Tarnowski, M., Goschorska, M., Barczak, K., Chlubek, D., \& Baranowska-bosiacka, I. (2020). Pre- and neonatal exposure to lead $\mathrm{Pb})$ induces neuroinflammation in the forebrain cortex, hippocampus and cerebellum of rat pups. International Journal of Molecular Sciences, 21(3). https://doi.org/10.3390/ijms21031 083
25. Cormick, G., Betrán, A., Romero, I., Lombardo, C., Gülmezoglu, A., Ciapponi, A., \& Belizán, J. (2019). Global inequities in dietary calcium intake during pregnancy: a systematic review and meta-analysis. BJOG: An International Journal of Obstetrics \& Gynaecology, 126(4), 444-456. https://doi.org/10.1111/1471-0528.15512

26. Davuljigari, C. B., \& Gottipolu, R. R. (2020). Late-life Cardiac Injury in Rats following Early Life Exposure to Lead: Reversal Effect of Nutrient Metal Mixture. Cardiovascular Toxicology, 20(3), 249-260. https://doi.org/10.1007/s12012 $-019-09549-2$

27. Dillard, C. J., \& Bruce German, J. (2000). Phytochemicals: Nutraceuticals and human health. In Journal of the Science of Food and Agriculture (Vol. 80, Issue 12, pp. 1744-1756). John Wiley \& Sons, Ltd. https://doi.org/10.100 2/1097-0010(20000915)80:12<1744::AID-JSF $\mathrm{A} 725>3.0 . \mathrm{CO} ; 2-\mathrm{W}$

28. Dubey, M. R., \& Patel, V. P. (2018). Probiotics: A Promising Tool for Calcium Absorption. The Open Nutrition Journal, 12(1), 59-69. https://d oi.org/10.2174/1874288201812010059

29. El-Ansary, A., Bjørklund, G., Tinkov, A. A., Skalny, A. V., \& Al Dera, H. (2017). Relationship between selenium, lead, and mercury in red blood cells of Saudi autistic children. Metabolic Brain Disease, 32(4), 1073-1080. https://doi.or g/10.1007/s11011-017-9996-1

30. El-Khadragy, M., Alolayan, E. M., Metwally, D. M., El-Din, M. F. S., Alobud, S. S., Alsultan, N. I., Alsaif, S. S., Awad, M. A., \& Moneim, A. E. A. (2018). Clinical efficacy associated with enhanced antioxidant enzyme activities of silver nanoparticles biosynthesized using moringa oleifera leaf extract, against cutaneous leishmaniasis in a murine model of leishmania major. International Journal of Environmental Research and Public Health, 15(5). https://doi.o rg/10.3390/ijerph15051037 
31. El-Masry, T. A., Emara, A. M., \& El-Shitany, N. A. (2011). Possible protective effect of propolis against lead-induced neurotoxicity in animal model. Journal of Evolutionary Biology Research, 3(1), 4-11. http://www.academicjour nals.org/jebr

32. Ettinger, A. S., Egan, K. B., Homa, D. M., \& Brown, M. J. (2020). Blood lead levels in U.S. women of childbearing age, 1976-2016. Environmental Health Perspectives, 128(1). ht tps://doi.org/10.1289/EHP5925

33. Ettinger, A. S., Hu, H., \& Hernandez-Avila, M. (2007). Dietary calcium supplementation to lower blood lead levels in pregnancy and lactation. Journal of Nutritional Biochemistry, 18(3), 172-178. https://doi.org/10.1016/j.jnutbi o.2006.12.007

34. Ettinger, A. S., Lamadrid-Figueroa, H., TéllezRojo, M. M., Mercado-García, A., Peterson, K. E., Schwartz, J., Hu, H., \& Hernández-Avila, M. (2009). Effect of calcium supplementation on blood lead levels in pregnancy: A randomized placebo-controlled trial. Environmental Health Perspectives, 117(1), 26-31. https://doi.org/10. 1289/ehp. 11868

35. Fahey, J. R. (2016). Microbiological monitoring of laboratory mice. In Genetically Engineered Mice Handbook (pp. 157-164). CRC Press. htt ps://doi.org/10.1201/9781420039078.ch12

36. Falkowska, A., Gutowska, I., Goschorska, M., Nowacki, P., Chlubek, D., \& BaranowskaBosiacka, I. (2015). Energy metabolism of the brain, including the cooperation between astrocytes and neurons, especially in the context of glycogen metabolism. In International Journal of Molecular Sciences (Vol. 16, Issue 11, pp. 25959-25981). MDPI AG. https://doi.org/10.3 390/ijms161125939

37. Fan, G., Feng, C., Li, Y., Wang, C., Yan, J., Li, W., Feng, J., Shi, X., \& Bi, Y. (2009). Selection of Nutrients for Prevention or Amelioration of Lead-Induced Learning and Memory Impairment in Rats. The Annals of Occupational Hygiene, 53(4), 341-351. https://doi.org/10.1093/ annhyg/mep019

38. Farid, A. S., \& Hegazy, A. M. (2020). Ameliorative effects of Moringa oleifera leaf extract on levofloxacin-induced hepatic toxicity in rats. Drug and Chemical Toxicology, 43(6), 616622. https://doi.org/10.1080/01480545.2019.15 74811

39. Flanagan, R. J., Taylor, A., Watson, I. D., \& Whelpton, R. (2008). Fundamentals of Analytical Toxicology. In Fundamentals of Analytical Toxicology. John Wiley \& Sons, Ltd. https://do i.org/10.1002/9780470516294

40. Gilbert, M. E., \& Lasley, S. M. (2002). Longterm consequences of developmental exposure to lead or polychlorinated biphenyls: Synaptic transmission and plasticity in the rodent CNS. Environmental Toxicology and Pharmacology, 12(2), 105-117. https://doi.org/10.1016/S13826689(02)00029-7

41. Gomaa, A., Hu, H., Bellinger, D., Schwartz, J., Tsaih, S. W., Gonzalez-Cossio, T., Schnaas, L., Peterson, K., Aro, A., \& Hernandez-Avila, M. (2002). Maternal bone lead as an independent risk factor for fetal neurotoxicity: A prospective study. Pediatrics, 110(1 I), 110-118. https://doi .org/10.1542/peds.110.1.110

42. Goyer, R. A. (1990). Transplacental transport of lead. Environmental Health Perspectives, 89, 101-105. https://doi.org/10.1289/ehp.9089101

43. Hassan, A. A., \& Jassim, H. M. (2010). Effect of treating lactating rats with lead acetate and its interaction with vitamin $\mathrm{E}$ or $\mathrm{C}$ on neurobehavior, development and some biochemical parameters in their pups. Iraqi Journal of Veterinary Sciences, 24(1), 45-52. https://doi.org/10.3389 9/ijvs.2010.5584

44. Hong, S.-B., Im, M.-H., Kim, J.-W., Park, E.J., Shin, M.-S., Kim, B.-N., Yoo, H.-J., Cho, I.-H., Bhang, S.-Y., Hong, Y.-C., \& Cho, S.-C. (2015). Environmental Lead Exposure and Attention Deficit/Hyperactivity Disorder Symptom Domains in a Community Sample of South 
Korean School-Age Children. Environmental Health Perspectives, 123(3), 271-276. https://d oi.org/10.1289/ehp.1307420

45. Jiraungkoorskul, K., \& Jiraungkoorskul, W. (2016). Moringa oleifera: A new challenge reducing heavy metal toxicity: A review. Indian Journal of Agricultural Research, 50(3), 199205. https://doi.org/10.18805/ijare.v0iOF.9361

46. Kandeil, M. A., Mohammed, E. T., Hashem, K. S., Aleya, L., \& Abdel-Daim, M. M. (2020). Moringa seed extract alleviates titanium oxide nanoparticles (TiO2-NPs)-induced cerebral oxidative damage, and increases cerebral mitochondrial viability. Environmental Science and Pollution Research, 27(16), 19169-19184. http s://doi.org/10.1007/s11356-019-05514-2

47. Kasolo, J. N., Bimenya, G. S., Ojok, L., Ochieng, J., \& Ogwal-Okeng, J. W. (2010). Phytochemicals and uses of Moringa oleifera leaves in Ugandan rural communities. Journal of Medicinal Plants Research, 4(9), 753-757. h ttps://doi.org/10.5897/JMPR10.492

48. Khalil, S. R., Abdel-Motal, S. M., Abd-Elsalam, M., Abd El-Hameed, N. E., \& Awad, A. (2020). Restoring strategy of ethanolic extract of Moringa oleifera leaves against Tilmicosininduced cardiac injury in rats: Targeting cell apoptosis-mediated pathways. Gene, 730. http s://doi.org/10.1016/j.gene.2019.144272

49. Kumar, A., Rai, A. K., Basu, S., Dash, D., \& Singh, J. S. (2008). Cord blood and breast milk iron status in maternal anemia. Pediatrics, 121(3). https://doi.org/10.1542/peds.200 $7-1986$

50. Kumari, D. J. (2010). HYPOGLYCAEMIC EFFECT OF MORINGA OLEIFERA AND AZADIRACHTA INDICA IN TYPE 2 DIABETES MELLITUS. In Save Nature to Survive (Vol. 5, Issue 2).

51. Ladele, J. I., Bamikeolu, I., Id, F., \& Chinyere Ezeaka, V. (2019). Determination of lead levels in maternal and umbilical cord blood at birth at the Lagos University Teaching Hospital, Lagos. https://doi.org/10.1371/journal.pone.0211535
52. Ladele, J. I., Fajolu, I. B., \& Ezeaka, V. C. (2019). Determination of lead levels in maternal and umbilical cord blood at birth at the Lagos University Teaching Hospital, Lagos. PLOS ONE, 14(2), e0211535. https://doi.org/10.1371 /journal.pone.0211535

53. Li, R. G., Li, T. T., Hao, L., Xu, X., \& Na, J. (2009). Hydrogen peroxide reduces leadinduced oxidative stress to mouse brain and liver. Bulletin of Environmental Contamination and Toxicology, 82(4), 419-422. https://doi.or $\mathrm{g} / 10.1007 / \mathrm{s} 00128-008-9599-\mathrm{y}$

54. Lidsky, T. I., \& Schneider, J. S. (2006). Adverse effects of childhood lead poisoning: The clinical neuropsychological perspective. Environmental Research, 100(2), 284-293. https://doi.org/ 10.1016/j.envres.2005.03.002

55. Liu, J., Cheng, H., \& Leung, P. W. L. (2011). The application of the preschool child behavior checklist and the Caregiver-Teacher Report Form to Mainland Chinese children: Syndrome structure, gender differences, country effects, and inter-informant agreement. Journal of Abnormal Child Psychology, 39(2), 251-264. http s://doi.org/10.1007/s10802-010-9452-8

56. Mahdy, T., Giorgi, M., Adewole, T., Ernest, F., Idoko, I., Matey, M., Ozele, N., Oladipo, S., \& Sunday, M. (2012). Effect of Moringa oleifera, activated carbon and wood charcoal on biochemical and hematological parameters of Wistar rats exposed to lead acetate. Medycyna Weterynaryjna, 68(02).

57. Maitra, S., \& Satardekar, K. (2017). ETHANOBOTANICAL STUDIES ON RUBIA CORDIFOLIA LINN. International Journal of Recent Scientific Research., 8(12), 22264-22267. http s://doi.org/10.24327/ijrsr.2017.0812.1234

58. Markowitz, M. (2000). Lead poisoning: A disease for the next millennium. Current Problems in Pediatrics, 30(3), 62-70. https://doi.org/10.1 067/mps.2000.104053 


\section{MEERP LTD}

59. Mason, L. H., Harp, J. P., \& Han, D. Y. (2014). $\mathrm{Pb}$ Neurotoxicity: Neuropsychological Effects of Lead Toxicity. BioMed Research International, 2014, 1-8. https://doi.org/10.1155/2014/ 840547

60. Mazumdar, M., Bellinger, D. C., Gregas, M., Abanilla, K., Bacic, J., \& Needleman, H. L. (2011). Low-level environmental lead exposure in childhood and adult intellectual function: A follow-up study. Environmental Health: A Global Access Science Source, 10(1), 24. http s://doi.org/10.1186/1476-069X-10-24

61. Metryka, E., Chibowska, K., Gutowska, I., Falkowska, A., Kupnicka, P., Barczak, K., Chlubek, D., \& Baranowska-Bosiacka, I. (2018). Lead (Pb) Exposure Enhances Expression of Factors Associated with Inflammation. International Journal of Molecular Sciences, 19(6), 1813. https://doi.org/10.3390/ijms19061 813

62. Metryka, E., Kupnicka, P., Kapczuk, P., Simińska, D., Tarnowski, M., Goschorska, M., Gutowska, I., Chlubek, D., \& BaranowskaBosiacka, I. (2020). Lead (Pb) as a factor initiating and potentiating inflammation in human THP-1 macrophages. International Journal of Molecular Sciences, 21(6). https://doi.org/10.3 390/ijms21062254

63. Mohamed, N., Mohamed, A., Abu-Aita, N., Nasr, S., Nassar, S., \& Ahmed, K. (2020). Moringa oleifera leaf ethanol extract ameliorates lead-induced hepato-nephrotoxicity in rabbits. Asian Pacific Journal of Tropical Biomedicine, 10(6), 263. https://doi.org/10.410 3/2221-1691.283940

64. Needleman, H. (2009). Low Level Lead Exposure: History and Discovery. In Annals of Epidemiology (Vol. 19, Issue 4, pp. 235-238). Elsevier Inc. https://doi.org/10.1016/j.annepide m.2009.01.022

65. Needleman, H. L., Schell, A., Bellinger, D., Leviton, A., \& Allred, E. N. (1990). The LongTerm Effects of Exposure to Low Doses of
Lead in Childhood. New England Journal of Medicine, 322(2), 83-88. https://doi.org/10.10 56/nejm199001113220203

66. Nicolescu, R., Petcu, C., Cordeanu, A., Fabritius, K., Schlumpf, M., Krebs, R., Krämer, U., \& Winneke, G. (2010). Environmental exposure to lead, but not other neurotoxic metals, relates to core elements of ADHD in Romanian children: Performance and questionnaire data'Study approval: This study has been reviewed and approved by the Ethics Committee of the "Romanian College of Physiciansthom. Environmental Research, 110(5), 476-483. htt ps://doi.org/10.1016/j.envres.2010.04.002

67. Nizioł-ŁUkaszewska, Z., Furman-Toczek, D., Bujak, T., Wasilewski, T., \& HordyjewiczBaran, Z. (2020). Moringa oleifera L. Extracts as Bioactive Ingredients That Increase Safety of Body Wash Cosmetics. Dermatology Research and Practice, 2020. https://doi.org/10.1155/202 0/8197902

68. Obeng-Gyasi, E., Armijos, R., Weigel, M., Filippelli, G., \& Sayegh, M. (2018). Cardiovascular-Related Outcomes in U.S. Adults Exposed to Lead. International Journal of Environmental Research and Public Health, 15(4), 759. https://doi.org/10.3390/ijerph15040 759

69. Oguntibeju, O. O., Aboua, G. Y., \& Omodanisi, E. I. (2020). Effects of Moringa oleifera on oxidative stress, apoptotic and inflammatory biomarkers in streptozotocin-induced diabetic animal model. South African Journal of Botany, 129, 354-365. https://doi.org/10.1016/j.sajb.20 19.08.039

70. Omóbòwálé, T. O., Oyagbemi, A., Aderoju, A., Adejumobi, O. A., Adedapo, A., Gbadamosi, I., \& Yakubu, M. (2020). Ameliorative effects of Moringa oleifera (MO) seeds on L-NAMEinduced hypertension in rats. The FASEB Journal, 34(S1), 1-1. https://doi.org/10.1096/fasebj .2020.34.s1.02556 
71. Owolabi, Joshua; Ghazal, O.k, Felicia, Williams; Ayodele, E. O. (2012). (13) (PDF) EFFECTS OF MORINGA OLEIFERA (DRUMSTICK) LEAF EXTRACTS ON LEAD-INDUCED TESTICULAR TOXICITY IN ADULT WISTAR RAT (RATTUS NOVERGICUS). International Journal of Biotechnology and Biomedical Research. htt ps://www.researchgate.net/publication/234167 221_EFFECTS_OF_MORINGA_OLEIFERA DRUMSTICK_LEAF_EXTRACTS_ON_LE AD-INDUCED_TESTICULAR_TOXICITY IN_ADULT_WISTAR_RAT_RATTUS_NOV ERGICUS

72. Qi, S., He, J., Chen, C., Zheng, H., \& Zhang, Z. (2019). Du-Zhong (Eucommia ulmoides Oliv.) cortex extract prevents bone loss in ovariectomized diabetic rats by suppressing bone turnover and upregulating OPG/RANKL ratios. In Int J Clin Exp Med (Vol. 12, Issue 7). www. ijcem.com/

73. Reckziegel, P., Dias, V. T., Benvegnú, D., Boufleur, N., Silva Barcelos, R. C., Segat, H. J., Pase, C. S., dos Santos, C. M. M., Flores, É. M. M., \& Bürger, M. E. (2011). Locomotor damage and brain oxidative stress induced by lead exposure are attenuated by gallic acid treatment. Toxicology Letters, 203(1), 74-81. https://doi.o rg/10.1016/j.toxlet.2011.03.006

74. Rees, N., Fuller, R., Narasimhan, G., Solomon, A., Design, A. B., Shangning, V., Editor, W., Research, D. M. P., Or Review, /, Choi, Y., Polo, F., Sripada, K., Stewart, L., Wickham, A., Xu, F., Yeasmin, S., Binkhorst, G., Caravanos, J., Ferraro, G., ... Rahona, E. (2020). United Nations Environment Programme) Desiree Raquel Narvaez (United Nations Environment Programme) Walker Smith.

75. Rehman Ali, S. K., , Marina Khan1, M. A., Ali, I., Taj, Khan5, A., Haleem1, S., Rooman6, M., Norin1, S., KhanID1, S. N., \& *. (2020). A systematic review of medicinal plants used against Echinococcus granulosus. https://doi.or $\mathrm{g} / 10.1371$ journal.pone. 0240456
76. Rossouw, J., Offermeier, J., \& van Rooyen, J. M. (1987). Apparent central neurotransmitter receptor changes induced by low-level lead exposure during different developmental phases in the rat. Toxicology and Applied Pharmacology, 91(1), 132-139. https://doi.org/10.1016/0041-0 08X(87)90200-6

77. Saghazadeh, A., \& Rezaei, N. (2017). Systematic review and meta-analysis links autism and toxic metals and highlights the impact of country development status: Higher blood and erythrocyte levels for mercury and lead, and higher hair antimony, cadmium, lead, and mercury. In Progress in Neuro-Psychopharmacology and Biological Psychiatry (Vol. 79, pp. 340-368). Elsevier Inc. https://doi.org/10.1016/j.pnpbp.20 17.07.011

78. Sánchez-Machado, D. I., López-Cervantes, J., \& Ríos Vázquez, N. J. (2006). Highperformance liquid chromatography method to measure $\alpha$ - and $\gamma$-tocopherol in leaves, flowers and fresh beans from Moringa oleifera. Journal of Chromatography A, 1105(1-2 SPEC. ISS.), 111-114. https://doi.org/10.1016/j.chroma.200 5.07 .048

79. Sanders, T., Liu, Y., Buchner, V., \& Tchounwou, P. B. (2009). Neurotoxic effects and biomarkers of lead exposure: A review. In Reviews on Environmental Health (Vol. 24, Issue 1, pp. 15-45). Freund Publishing House Ltd. ht tps://doi.org/10.1515/REVEH.2009.24.1.15

80. Sharayu, R., \& Asmita, M. (2017). Beneficial effect of Moringa oleifera on Lead induced Oxidative stress. In International J. of Life Sciences (Vol. 5, Issue 1). www.ijlsci.in

81. Sharma, V., Kansal, L., Sharma, A., Lodi, S., \& Sharma, S. H. (2011). Ameliorating Effect of Coriandrum sativum Extracts on Hematological and Immunological Variables in an Animal Model of Lead Intoxication. Journal of Pharmacy and Allied Health Sciences, 1(1), 16-29. https://doi.org/10.3923/jpahs.2011.16.29 
82. Shell, E. R. (2016). Gauging the effects of lead. In Scientific American (Vol. 315, Issue 1, pp. 23-24). Scientific American Inc. https://doi.org /10.1038/scientificamerican0716-23

83. Sioen, I., Den Hond, E., Nelen, V., Van de Mieroop, E., Croes, K., Van Larebeke, N., Nawrot, T. S., \& Schoeters, G. (2013). Prenatal exposure to environmental contaminants and behavioural problems at age 7-8years. Environment International, 59, 225-231. https://doi.org $/ 10.1016 /$ j.envint.2013.06.014

84. Smith, M. R., Yevoo, P., Sadahiro, M., Austin, C., Amarasiriwardena, C., Awawda, M., Arora, M., Dudley, J. T., \& Morishita, H. (2018). Integrative bioinformatics identifies postnatal lead $(\mathrm{Pb})$ exposure disrupts developmental cortical plasticity. Scientific Reports, 8(1). https://doi.o $\mathrm{rg} / 10.1038 / \mathrm{s} 41598-018-34592-4$

85. Tatsuta, N., Nakai, K., Kasanuma, Y., IwaiShimada, M., Sakamoto, M., Murata, K., \& Satoh, H. (2020). Prenatal and postnatal lead exposures and intellectual development among 12-year-old Japanese children. Environmental Research, 189, 109844. https://doi.org/10.1016 /j.envres.2020.109844

86. Toews, A. D., Kolber, A., Hayward, J., Krigman, M. R., \& Morell, P. (1978). Experimental lead encephalopathy in the suckling rat: Concentration of lead in cellular fractions enriched in brain capillaries. Brain Research, 147(1), 131-138. https://doi.org/10.1016/0006-8993(7 8)90777-1

87. Torabi, Z., Halvachi, M., Mohseni, M., \& Khederlou, H. (2018). The relationship between maternal and neonatal umbilical cord blood lead levels and their correlation with neonatal anthropometric indices. Journal of Comprehensive Pediatrics, 9(1). https://doi.org/10.5812/co mpreped.55056

88. Verina, T., Rohde, C. A., \& Guilarte, T. R. (2007). Environmental lead exposure during early life alters granule cell neurogenesis and morphology in the hippocampus of young adult rats. Neuroscience, 145(3), 1037-1047. https:// doi.org/10.1016/j.neuroscience.2006.12.040

89. Vigeh, M., Saito, H., \& Sawada, S. I. (2011). Lead exposure in female workers who are pregnant or of childbearing age. Industrial Health, 49(2), 255-261. https://doi.org/10.2486/indhea 1th.MS1192

90. Wani, A. L., Ara, A., \& Usmani, J. A. (2015). Lead toxicity: A review. In Interdisciplinary Toxicology (Vol. 8, Issue 2, pp. 55-64). Slovak Toxicology Society. https://doi.org/10.1515/int ox-2015-0009

91. Weitzman, M., \& Kursmark, M. (2009). Breastfeeding and Child Lead Exposure: A Cause for Concern. In Journal of Pediatrics (Vol. 155, Issue 5, pp. 610-611). Elsevier. https://doi.org /10.1016/j.jpeds.2009.05.035

92. William, F., Lakshminarayanan, S., \& Chegu, H. (1993). Effect of some indian vegetables on the glucose and insulin response in diabetic subjects. International Journal of Food Sciences and Nutrition, 44(3), 191-195. https://doi.org/1 $0.3109 / 09637489309017439$

93. World Health Organisation. (2010). Childhood Lead Poisoning.

94. World Health Organisation. (2013). Lead poisoning and health. In Saudi Medical Journal (Vol. 34, Issue 10). https://www.mendeley.co $\mathrm{m} /$ catalogue/5535dcab-4559-386c-8a45-1d78c $18 \mathrm{bd} 7 \mathrm{ac} /$ ?utm_source=desktop\&utm_medium $=1.19 .4 \& u t m \_$campaign $=$open_catalog\&userD ocumentId $=\%$ 7 $7 \mathrm{Bc} 563 \mathrm{~d} 191$-c1 1 f0-313f-9003-c7 f65d0ab9d5\%7D

95. World Health Organisation. (2016). WHO | Childhood Lead Poisoning. In WHO. World Health Organization. http://www.who.int/ceh/p ublications/childhoodpoisoning/en/

96. World Health Organisation. (2020). Lead poisoning and health. https://www.who.int/ne ws-room/fact-sheets/detail/lead-poisoning-and -health 
97. Wright, J. P., Dietrich, K. N., Ris, M. D., Hornung, R. W., Wessel, S. D., Lanphear, B. P., Ho, M., \& Rae, M. N. (2008a). Association of Prenatal and Childhood Blood Lead Concentrations with Criminal Arrests in Early Adulthood. PLoS Medicine, 5(5), e101. https://doi.org/10.1 371/journal.pmed.0050101

98. Wright, J. P., Dietrich, K. N., Ris, M. D., Hornung, R. W., Wessel, S. D., Lanphear, B. P., Ho, M., \& Rae, M. N. (2008b). Association of Prenatal and Childhood Blood Lead Concentrations with Criminal Arrests in Early Adulthood. PLoS Medicine, 5(5), e101. https://doi.org/10.1 371/journal.pmed.0050101

99. Yousef, A. O. S., Fahad, A. A., Moneim, A. E. A., Metwally, D. M., El-Khadragy, M. F., \&
Kassab, R. B. (2019). The neuroprotective role of coenzyme Q10 against lead acetate-induced neurotoxicity is mediated by antioxidant, antiinflammatory and anti-apoptotic activities. International Journal of Environmental Research and Public Health, 16(16). https://doi.org/10.33 90/ijerph16162895

How to cite this article: Osuh J.I., Sunmola A.M., Balogun S.K., Ishola A.A. Evaluation of Blood Lead Levels (BII) of Albino Rat Offspring (Weanlings) Prenatally Exposed to Lead and Moringa Oleifera. Journal of Medical Research and Health Sciences. 2021;1610-1628. https://doi .org/10.52845/JMRHS/2021-4-12-3 